\title{
Oriental Pages of the Early Poetry of V.V. Nabokov
}

\author{
Safiulina Rano Mirsachanovna ${ }^{1}$ \\ Associate Professor of Russian Language and Literature, Moscow University for \\ Industry and Finance «Synergy», \\ Moscow, Russia.
}

(date of receiving: November, 2019; date of acceptance: February, 2020)

\begin{abstract}
The article deals with the problem of Orientalism in the works of V.V. Nabokov of the early Russian-speaking period. In this connection, works are researched that imply the theme and figurative and artistic specificity of the East, oriental allusions and reminiscences in poems of the Russian writer of the first period of emigration. The relevance of the study is due to the need to state and highlight the problems of Oriental traditions in the work of Nabokov, as his oriental images, genres, style became a continuation of the Orientalism of Pushkin, Shakespeare, Goethe, Bunin, Gumilev and at the same time, a new word in the artistic interpretation of the East of the 20th century. The novelty of the research is seen in the fact that for the first time in literary criticism, the problem of Eastern traditions is raised in the early poetry of Nabokov. It reveals the specifics of Nabokov's inclusion of eastern reminiscences in the texts of his works. The results of a comparative analysis of the "eastern" images and key lexemes in the works of Pushkin and Nabokov, Gumilyov and Nabokov are presented as a poetic dialogue and a roll of poets. The significance of this dialogue in the construction of Nabokov's poetic world is revealed.
\end{abstract}

Keywords: Nabokov V.V., East, Orientalism, Metatheme, Polygenetic, Homeland.

1. Email: ranovi@mail.ru 


\title{
Ориентальные страницы ранней поэзии В.В. Набокова
}

\section{Сафиулина Рано Мирзахановна ${ }^{1}$}

Доцент кафедры русского языка и литературы МФПУ «Синергия»,

\author{
Москва, Россия.
}

(дата получения: ноябрь 2019 г.; дата принятия: февраль 2020 г.)

\begin{abstract}
Аннотация
В статье рассматривается проблема ориентализма в творчестве В.В. Набокова раннего русскоязычного периода. В связи с этим исследуются произведения, имплицирующие тему и образно-художественную специфику Востока, восточные аллюзии и реминисценции в стихотворениях русского писателя первого периода эмиграции. Актуальность исследования обусловлена необходимостью постановки и освещения проблемы ориентальных традиций в творчестве Набокова, так как его восточные образы, жанры, стилистика стали продолжением ориенталистики Пушкина, Шекспира, Гете, Бунина, Гумилева и, одновременно, новым словом в художественной интерпретации Востока XX века. Новизна исследования видится в том, что впервые в литературоведении поднимается проблема восточных традиций в ранней поэзии Набокова. Раскрывается специфика включения Набоковым восточных реминисценций в тексты своих произведений. Представлены результаты сопоставительного анализа «восточных» образов и ключевых лексем в произведениях Пушкина и Набокова, Гумилева и Набокова как поэтический диалог и перекличка поэтов. Выявляется значение этого диалога в построении поэтического мира Набокова.
\end{abstract}

Ключевые слова: Набоков В.В., Восток, Ориентализм, Метатема, Полигенетичность, Родина.

1. Email: ranovi@mail.ru 


\section{Введение}

Без освоения богатейшей культуры Востока невозможно представить во всей полноте мировой и русский литературный процесс. Поэтому русские писатели в большей или меньшей степени отдали дань уважения и почитания теме Востока в своем творчестве. «Таким образом русские писатели мыслители, как и другие европейские, смогли преодолеть духовную пустоту, которую они чувствовали в своей работе» (Яхьяпур М., Карими-Мотаххар Дж., 2018. 182). В связи с этим тема русского ориентализма - одна из самых исследованных в литературоведении России. Однако научная проблема восточных традиций в творчестве В.В. Набокова остается пока неосвещенной. Причина неизученности рецепции Востока в художественном мире писателя можно объяснить бытованием мнения, что Набоков - западник по воспитанию, общественным ориентирам, образу жизни и мысли и мир Востока чужд ему.

Однако внимательное прочтение произведений писателя свидетельствует о глубоком понимании и своеобразном включении восточных мотивов, образов, стилистики в ткань своих текстов. Следовательно, в литературоведении назрела необходимость изучение данной проблемы.

\section{Основная часть}

Владимир Набоков (1899 - 1977), писатель и критик, освоивший все культурные достижения русской литературы XIX века во всей ее глубине и многообразии, сложности и самобытности. После революции 1917 года девятнадцатилетним юношей В. Набоков покинул Родину, и началась его скитальческая жизнь: сначала Крым, Константинополь, Стамбул, Берлин, Франция. Позже, переехав в Америку, он преподавал в американских университетах и начал писать свои произведения на английском языке.

Первая книга В.Набокова «Стихи» вышла в свет в 1916 году. Несмотря на внушительный список стихотворных сборников, критики считают поэзию 
Набокова лишь приложением к его блистательной и оригинальной прозе. Так, А.М. Люксембург в статье «Тень русской ветки на мраморе руки» пишет: «И действительно, стихотворения Набокова не главное из написанного. Это «стихи прозаика». Но это нисколько не умаляет их ценности» (Люксембург 2001. 8).

Русскоязычная поэзия Набокова первых лет эмиграции (сборники «Гроздь» 1922 г., «Горний путь» 1923 г.) ценна тем, что стихи появились в ощущении катастрофы и потрясения, первых лет эмиграции, бегства с толпой несчастных, бесприютных беженцев через Черное море, скитания по Турции, Европе без дома, без денег, без прежних особняков, имений, библиотек, слуг. Темы, образы, лихорадочно возникающие под пером молодого поэта, воспроизведены в потоке памяти, естественном субъективном протекании, в вихре страданий, тревог, размышлений.

События 1917 - 1919 гг. были настолько сильными, что тема России, тоски о ней, возвращения домой станут метатемами всего художественного пути писателя. Даже позже, будучи скрытым за маской англоязычного преуспевающего писателя, за своими прозаическими мистификациями, Набоков напишет по-русски строки о родине, наполненные тоской и бесприютностью:

\section{Итака (1951 г.)}

Был день как день. Дремала память. Длилась

холодная и скучная весна.

Внезапно тень на дне замевелилась -

и поднялась с рыданием со дна.

О чем рыдать? Утешить не умею.

Но как затопала, как затряслась, 


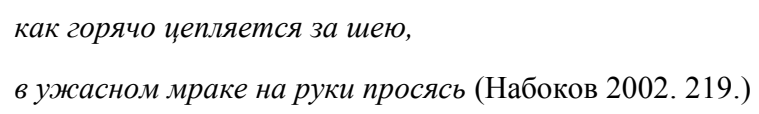

Отголоски детской и юношеской памяти о России, ее лесах, лугах, березах, болотах и озерах, русской речи, первой любви будут потаенно биться и трепетать в самых далеких уголках сердца поэта, и за границей, в Германии и Америке, поэт будет мысленно возвращаться домой, к поруганной и обманутой России (как он ее называл). Ретроспективный взгляд на Родину, на прошлое, счастливое время детства и юности, родные дали и места создали своеобразный стиль поэзии В. Набокова первых лет эмиграции, который сохранился и в «русскоязычной» прозе писателя. Созданные поэтическим вдохновением образы, связанные с прошлым, станут обволакиваться флером воспоминаний - сладких и бесконечно дорогих. Образы станут превращаться в сны, в мечты, порой - страдальческий бред и галлюцинации.

Мотив возвращения домой неизменно сопровождается в творчестве Набокова образами призрака, тумана, небытия. Дух поэта мечется и страдает, ностальгические воспоминания не дают спать, и только воплощаясь в призрак, тайными, неведомыми, забытыми путями он в своих мечтах может вернуться в родные края. Пробуждение всегда тяжело и пессимистично - оно означает «никогда» - никогда в реальности он не вернется домой.

Герой романа «Дар» будет мечтать в старости: «Быть может, когда-нибудь, на заграничных подошвах и давно сбитых каблуках, чувствуя себя привидением, ... я сойду на той станции и без всяких спутников, пешком пройду стежкой шоссе с десяток верст до Лещина... Мне кажется, что при ходьбе я буду издавать нечто вроде стона в тон столбам...» (Набоков 1998. Т.: 3. 24).

Поэзия Набокова и раннего (русскоязычного), и позднего (англоязычного) периодов корнями уходит в русскую поэзию XIX и серебряного веков. Своим учителем писатель называл А.С. Пушкина. Всё, что было связано с именем и 
творчеством великого русского поэта, окружено в памяти В.Набокова нежностью и любовью. Он гордился тем, что родился спустя 100 лет после рождения Пушкина. Образы пушкинских творений, изящество его стиля, судьба поэта, Санкт-Петербург -город, с которым связаны его детство и юность, - всё воссоздаётся в поэзии В.Набокова со священным трепетом. Позже, давая оценку своему творчеству, поэт напишет в стихотворении «Поэт, печалью промышляя» (Берлин, 1931г.):

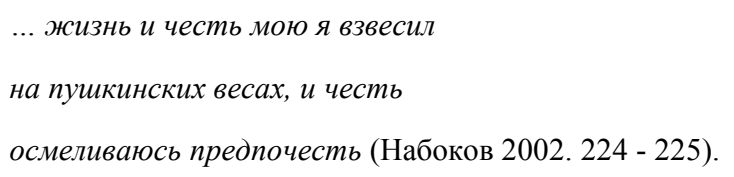

Мировоззрение раннего русскоязычного В. Набокова соткано из научных открытий мира, христианских, пантеистических воззрений. «Вообще, Набокову свойственна зоркость и, можно сказать, безжалостность в изображении человека. Люди занимают писателя как очень интересный объект почти что естественнонаучного наблюдения» (Накарякова 2016. 9). Культурологический фон его творчества - А.С. Пушкин, В. Шекспир, Данте. Ф.И. Тютчев, А.А. Фет, Л.Н. Толстой, И.А. Бунин, А.А. Блок, Н.С. Гумилев. Парафразы из произведений этих писателей войдут органично в текст его собственных сочинений.

Мир, созданных в снах и видениях поэта, наполненный импрессионистическими оттенками, световыми и звуковыми пятнами, светотенями мимолетных видений - этот мир радует счастливой принадлежностью к вечному бытию, единством, неразделенностью на до и после эмиграции.

... чтоо во всем и во всем тихий бог, тайный бог 


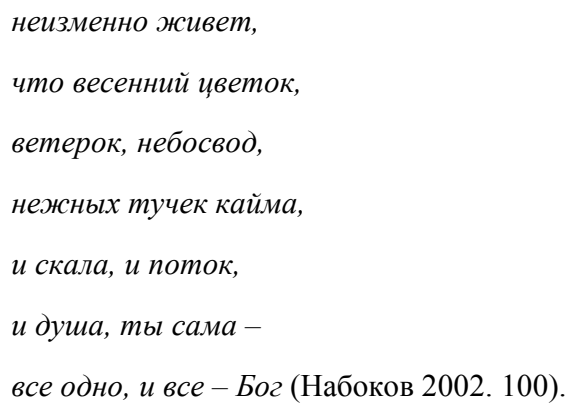

В стихотворении слышны отзвуки поэзии А.А. Фета. «Еще одна особенность, объединяющая Набокова и Фета, - своеобразный гедонизм, способность восхищаться первозданной красотой мира, находя ее даже в самых простых, незатейливых вещах и повседневных явлениях» (Карпов 2017. 32). Удаль широкая, русская, реминисценции из Державина, Пушкина, Лермонтова придают настроению стихотворению именно русский характер «русскость», как форму ностальгии по Родине.

Набоков создал в своих произведениях особый цветовой и звуковой образ России. Сны о покинутой родине как память о промелькнувшем счастье станут с годами яркими, многоцветными. Так возникнут импрессионистические картины Родины в творчестве В. Набокова. Любимые с детства звуки фортепьяно, летящие из открытого окна в простор полей и неба, звуки русской речи, пение птиц, еле слышное движение бабочек в темном воздухе - это «очарование звуковое» Родины. Этот мир не существует в реальности - он сохранился лишь в душе поэта, но для него он ближе и роднее, чем жестокая, грубая реальная жизнь. «Бытие поэта разворачивается в двух мирах: действительности и вымысла, - и неизвестно, какой из них реальнее. Перерыв бытия, отключение времени в одном из них означает новый отсчет времени в другом мире» (Погребная 2005. 27).

Набоковские образы-полутени сотканы из «тени и света воздушных звуков», они воздействуют на читателя «дыханием легким» стиха, внутренней 
тонкостью и мимолетностью. Пушкинское «мимолетное видение» станет доминантой образной структуры поэзии В. Набокова. Видение жизни из окна поезда, парохода, окна, видение - сон, мечта наполняют мир В. Набокова поэта.

Порой в этих видениях проплывают и «восточные» образы. Но они слишком рафинированны, эфемерны, выдержаны в европейских традициях, скорее, это отголоски, поэтическое эхо ориентальных произведений Д. Байрона, Т. Мура, А.С. Пушкина, М.Ю. Лермонтова, И.А. Бунина, Л.Н. Толстого, Н.С. Гумилева. «Мы можем говорить об особом литературном обрамлении всей творческой жизни Набокова. Речь идет даже не столько о влияниях и традициях классики XIX в., сколько о самом литературном мире, существовавшем в воображении писателя и бывшем для него, по-видимому, большей реальностью, чем действительный окружающий мир. Этот литературный мир, оставленный ему классиками, дробился, множился, переосмысливался, тематически развивался и влиял на образы, рожденные собственной фантазией художника» (Целкова 2011. 50).

Только через призму этих произведений русской классики проступают, как эхо, шедевры персидских поэтов Саади, Хафиза, Руми, Хайяма. Эти художественные изыскания молодого поэта представляют собой эстетически обозначенные вариации на отдельные фрагменты идей, тем, образов, поэтики восточной культуры (именно культуры, а не только литературы). Источниками восточных произведений в целом и отдельных восточных аллюзий в «западных» текстах Набокова могут служить и ориентальные произведения живописи, балета, театра, философии, созданные в разные исторические эпохи, но ставшими «своими» в европейской культуре, в целом - мировой культурной памяти. «Единственно достойный предмет истинного искусства жизнь воображения, понимаемого как форма памяти, вобравшей в себя личный и культурный опыт человечества, а значит, не только его личные 
воспоминания, но и память о том необъятном мире художественного вымысла, который предоставляет ему искусство» (Злочевская 2018. 40). Исследователь вводит новые термины, раскрывающие специфику обращения Набокова с традицией классического искусства: «полигенетичность», «снятие» литературной традиции» (Злочевская 2018. 41). Такими отголосками «восточного» можно назвать стихотворения Набокова «Живи. Не жалуйся...» (1919 г.), «Паломник» (1920 г.), «Глаза» (1920 г.), «Жук» (1922 г.), «Пир» (1921 г.), «Жемчуг» (1923 г.), «Властелин» (Я Индией невидимой владею) (1923 г.).

«Восточный» элемент в ранней поэзии Набокова эмигрантской поры симптоматичен во многом. Обращение поэта к восточным мотивам и образам происходит в результате исследовательского интереса и, одновременно, поэтической игры - стилизации. Включение восточных аллюзий в поэзии Набокова происходит на уровне потока памяти, это Восток, как сегмент всемирной культуры, итог осмысления и интерпретации ориентальных мотивов в мировой литературе, живописи, музыке предшествующих веков. В памяти Набокова «восточное» включается в его видение родины, прежней России.

Поэзия писателя показательней в этом плане, чем его проза. Если в прозаических произведениях Набокова господствует «маска», мистификация, пародия, то поэзия его откровенна, открыта. Поток ассоциаций, дискурсов, реминисценций, отголосков прошлого настолько проникнут болью переживания, отчаянием, безнадежностью, что автор забывает о поэтической игре и предстает перед читателями с обнаженным сердцем, что крайне редко происходит в творчестве Набокова - прозаика.

Стихотворение «Живи. Не жалуйся...» (1919) построено на противопоставлении мотивов смертности человека и бессмертности божественного бытия. В повелительной форме заветов бесспорно влияние поэзии А.С. Пушкина. В.Набоков далек от точного текста стихотворений 
своего великого предшественника, он лишь воспроизводит А.С. Пушкина по памяти.

\section{У А.С. Пушкина:}

Мужайся, презирай обман,

Стезею правды бодро следуй,

Люби сирот и мой Коран

дрожащей твари проповедуй (Пушкин 1977. 206).

В. Набоков так интерпретирует кораническое произведение А.С. Пушкина:

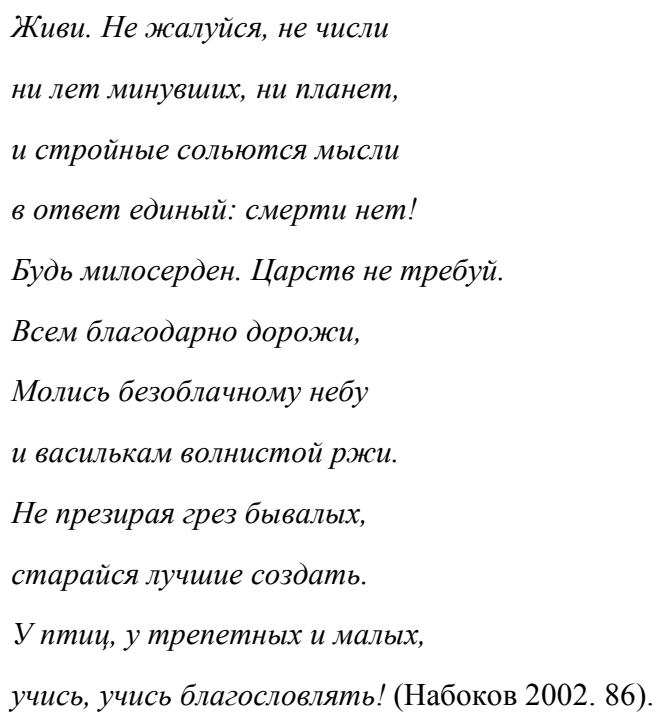

Набоков переводит общественное звучание «Подражание Корану» Пушкина в личный характер своего произведения. Молодой поэт уходит от общественно-нравственных аспектов стихотворения Пушкина. Набоков словно ищет рецепты утешения и успокоения своей изболевшей душе. На первый крупный план он выдвигает себя, свои переживания, размышления, боль своей души, одиночество, отчаяние. Спасение для него в этот трудный момент - красота, гармония, вселюбие божьего мира. Полюбить величие и 
красоту бессмертного божественного мира, научиться жить в гармонии с окружающей природой, быть милосердным, терпеливым, всепрощающим - в этом Набоков находит свой рецепт душевного покоя. Это вселенское чувство божественной любви призывает его жить, любить, благословлять каждый миг бытия. Только оно рождает надежду, мысли о спасении.

Личностный характер стихотворения, гиперболическое осмысление «Я»в контексте мироздания, на планетарном уровне, суровость интонации, усвоенная из стихотворения Пушкина, преднамеренное следование, точное копирование композиционной структуры текста великого предшественника новаторство Набокова, но, одновременно, и своеобразный итог творческой интерпретации Востока в русской поэзии XIX и начала XX веков. «В древневосточных памятниках они (русские писатели - Р. С.) находили ту гармонию человека с природой, тот примат чувства над разумом, что отражение «тайнописи» бытия, которые, с их точки зрения, составляет предпосылки любого высокого искусства» (Каменский 1980. 9).

Коранические мотивы органически входят и в другие произведения Набокова. В стихотворении «Крым» (1920г.) полуостров ассоциируется с восточным раем - благоуханным, прекрасным, чарующим.

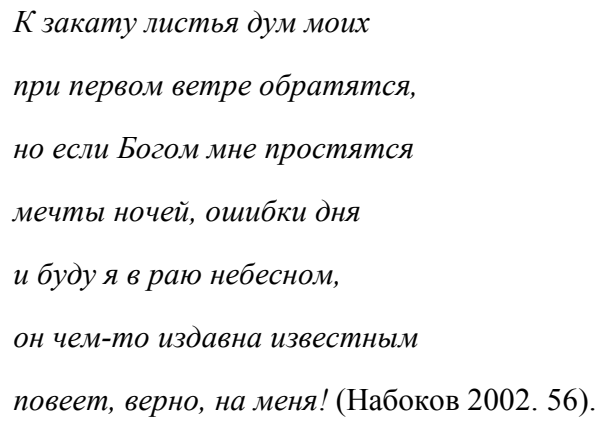

В стихотворении В. Набокова «Санкт-Петербург» (1924) звучат дискурсы в пушкинские стихотворения «От меня вчера Леила», «Заклинание», «Город 
пышный, город бедный». Образ Леилы возникает в творчестве Пушкина как реминисценция из стихотворения «Лалла Рук» и поэмы «Ангел и Пери» В.А. Жуковского. «Прекрасный образ гения красоты явился перед взором поэта, но видение это было кратко и мимолетно. Образ исчез, «жизнь минуты озарив». Но мимолетное видение прекрасной девы раскрывает лирическому герою Истину - тайну единства мироздания, «всеобщего бытия», божество» (Сафиулина 2009. 166). Прекрасная Леила, но уже как тень, появляется и в стихотворении Пушкина «Заклинание» (1831 г.)

\footnotetext{
- Я тень зову, я жду Леиль:

Ко мне, мой друг, сюда, сюда!

Явись, возлюбленная тень,

Как ты была перед разлукой,

Не для того, что иногда

Сомненьем мучусь... но тоскуя

Хочу сказать, что всё люблю я,

Что всё я твой: сюда, сюда! (Пушкин 1977. 314).
}

В стихотворении Набокова образ исчезнувшей навсегда Леилы сопряжен с воспоминанием о Санкт-Петербурге - прекрасным городом юности поэта. Образы Пушкина преломляются в зеркале времени и памяти.
Ко мне, туманная Леила!
Весна пустынная, назад!
Бледно-зеленые ветрила
двориовый распускает сад.
Орль мерияают вдоль опушки,
Нева, лениво шелестя, 


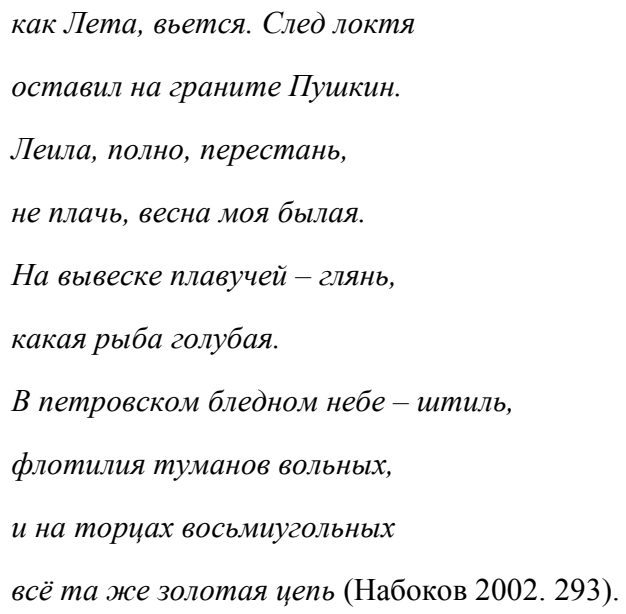

Набоков умеет точно «вкраплять» пушкинский текст в фактуру своего стиха, наподобие драгоценных камней в золотую оправу. В своем стихотворении он создает прекрасную цепь из пушкинских выражений и слов из произведения великого писателя «Город пышный, город бедный»: «свод небес зелено-бледный», «гранит», «след стройной ножки», «локон золотой».

Метатема получает иной смысл. Не человек, а эпоха. Не ушедшая красавица, а ушедшее время, растворившееся безвозвратно и навсегда. Любимый город - «весна моя былая» - остался в памяти поэта. Его приметы, облик превращаются в «золотую пыль». Так, мотив восточной красавицы, воплотившийся в творении Пушкина, находит новую интерпретацию Набокова. Все бессилие человека перед этим безжалостным роком, острота боли и тоски человеческого сердца, оторванного от любимой, является эмоциональной темой стихотворения Пушкина. Но в воплощении Набокова эта романтическая тема, исходящая к суфизму, превращается в тему страдания человеческого сердца, оторванного от любимой родины.

Набоков отказывается от суфийского подтекста, и Леила для него отголосок его культурной памяти. Возвращение назад, в прошлое невозможно, 
как невозможно возвращение призрака красавицы, молодости. И бесполезны мольбы, просьбы «Назад!», «Ко мне!».

В другом стихотворении - «Паломник» (1927г.), посвященном другу, товарищу по берлинской эмиграции, критику Ю. Айхенвальду (1832-1928), поэт сопоставляет это страстное желание вернуться домой, в прошлое со счастьем паломника, стремящегося попасть в Мекку - долгожданную мечту своего скитания по трудному пути, высшую цель и сверхзадачу жизни.

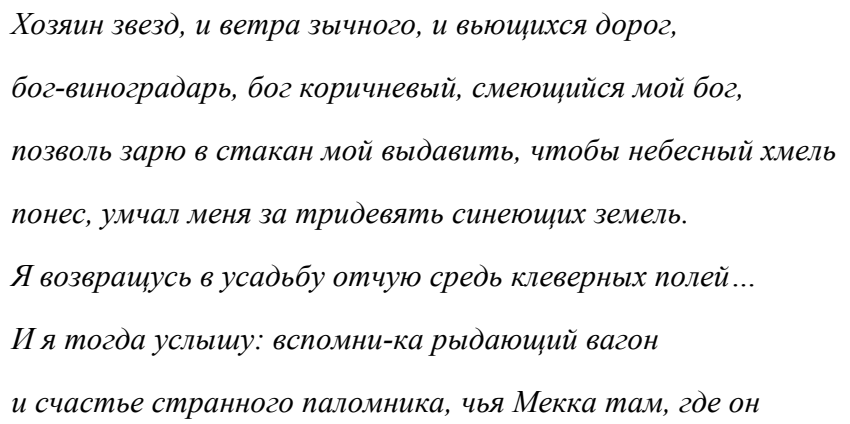

(Набоков 2002. 190).

Тема паломника, мечтающего о Мекке, была очень популярна в русской поэзии конца XIX - начала XX веков. О паломнике написали свои стихотворения И. Бунин, Н. Гумилев, вдохновившиеся «Кораном» в переводе К. Николаева.

Истинный смысл жизни и бытия, совершенство Набоков находит в своей памяти - это воспоминание о Родине. Родина воплотилась для Набокова в священную Мекку - страстную мечту паломников, бредущих по трудным жизненным тропам.

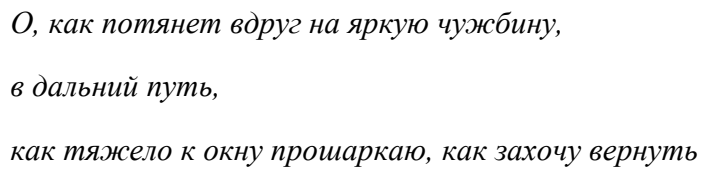


все то дрожащее, весеннее, что плакало во мне,

и-всякой яви совершеннее - сон о родной стране

(Набоков 2002. 190).

Набоков воспринял и воплотил в своем творчестве такую традиционную черту персидской литературы как красочный женский образ, который выступает воплощением божественного совершенства, божественной истины (в суфийском понимании). В стихотворении «Глаза» (1920 г.) поэт обращается к традициям Пушкина «Ответ Ф. Т.» («Нет, не черкешенка она»). Традиционное для Востока сравнение с драгоценными камнями (о чем писали Гете, Гегель, Шекспир, Байрон), высокое эмоциональное чувство, возвышенность эпитетов и сравнений явно говорят о «восточных» корнях стихотворения Набокова «Глаза»:

\footnotetext{
Напев сквозных ичикад умрет в листве олив, погаснут светляки на гиацинтах смятых, но сладостный разрез твоих продолговатых атласно-темных глаз, их ласка, и отлив чуть сизый на белке, и блеск на нижней веке, и складки нежные над верхнею, - навеки останутся в моих сияющих стихах, и людям будет мил твой длинный взор счастливый, пока есть на земле цикады и оливы и влажный гиацинт в алмазных светляках (Набоков 2002. 75).
}

Набоков создает очаровательную «персидскую миниатюру», навеянную аллюзиями из персидской поэзии, сказок «1001 ночи», «Западно-восточного дивана» Гёте, Гумилева, Кузмина. Нега Востока, томность, цветы и драгоценности, любовь как путь к бессмертию в сочетании с изысканностью и 
пышностью поэтики уводят читателя в «страну далекую, древнюю». В контексте стихотворения Набокова звучит и аллюзии из «Эзбикие» Гумилева. Набоков ретроспективно, намеренно в стиле Гумилева, воспроизводит картину прекрасного, благоуханного сада как воплощение рая, используя прием экфрасиса для описания божественной красоты деревьев, цветов, водопадов. Приглушенные звуки ночного сада, пение цикад, обеты вечной любви, влажные гиацинты, блеск алмазных светляков - всё это ретроспектирует чарующий мир Востока. И облик прекрасной царевны, и благословенный мир, запечатленный в стихотворении, будет навеки сохранен благодаря вечному искусству.

Часто в творчестве Набокова один и тот поэтический объект получает разные интерпретации. Так, позже, в повести «Приглашение на казнь» Набокова роскошный парк раскрывается уже в другом значении. «...пространство Тамариных Садов знаменует утраченное счастье, потерянное ощущение единства с мирозданием» (Карпов 2017. 103). Эта особенность дает возможность исследователю так трактовать стиль Набокова-писателя: «Однако специфика изображаемой картины в том, что она явно создается как плод поэтического воображения, способного задавать конструируемому миру какие угодно рамки» (Карпов 2017. 29).

Набоков неоднократно использовал в своем раннем поэтическом творчестве и форму восточной притчи-сказки. Эта поэтическая форма позволила поэту расширить рамки культурного пространства. Молодой поэт словно проверял свои возможности освоения разносторонних культурных стилей и жанров. Такой нарративный «восточный мир» (в европейском усвоении) присутствует (не без влияния Н.С. Гумилева) в стихотворениях Набокова «Пир» (1921 г.), «Жемчуг» (1923 г.). В 1927 году Набоков высказался о необходимости занимательности, интересности стихов. Поэтому он предложил писать сюжетные стихотворения, в качестве примера избрав 
поэзию любимого Гумилева: «О Гумилеве нельзя говорить без волненья. Придет время, когда Россия будет им гордиться. Читая его, понимаешь, между прочим, что стихотворение не может быть просто «настроением», «лирическим нечто», подбором случайных образов, туманом и тупиком. Стихотворение должно быть прежде всего интересным. В нем должна быть своя завязка, своя развязка. Читатель должен с любопытством начать и с волненьем окончить» (Набоков 2002. 28)

В стихотворении «Жук» (1922 г.) Набоков актуализирует весь пышный арсенал восточных образов, столь характерных для русской ориенталистики. Здесь вся атрибутика поэзии Востока: «кипарис», «звездочет», «соловей», «роза» («лепестков блаженной розы», «рдяная роза»), «луна», «драгоценности» («живой сапфир»), «пеоны», «мимоза», «локоны» девы, «поэт». Кажется, что Набоков с удовольствием погружается в мир благоуханной восточной притчи в духе Хафиза и Саади. Тонкая «игра» смыслами, мотивами, образами в модернистском понимании предназначена для подготовленного читателя, хорошо ориентирующегося в культурном пространстве персидской поэзии. Божественный животворящий мир оказывается совершеннее и прекраснее, чем творчество поэта - такова мысль Набокова в этом произведении.

В саду, где кипарис, как черный звездочет,

стоит над лунною поляной,

где соловьиный звон всю ночь течет, течет, -

кто, кто любезен розе рдяной?

Не мудрый кипарис, не льстивый соловей,

а бог сапфирный, жук точеный;

с ним роза счастлива... Поэт, нужны ли ей

твои влюбленные пэоны? (Набоков 2002. 255). 
Стихотворение Набокова «Властелин» (Я Индией невидимой владею)» (1923 г.) навеяно восточными произведениями Н.С. Гумилева. В нем задействован весь поэтический ареал поэта - путешественника («павлин», «барс», «пальмовые чащи», «тяжелозвездный небосклон»). Выражение «Я Индией невидимой владею» звучит как аллюзия знаменитой мифологемы Гумилева «Индия духа». Тема любви в стихотворении звучит отголосками «Персидской тетради» любимого поэта.

\section{Заключение}

Набоков создал свой уникальный художественный мир, в котором переплетаются его переживания о мире, человеке, природе, творчестве, любви, жизни. На первый план в его творчестве выходит гиперболическое осмысление «Я», личное переживание поэта. Русскоязычная поэзия Набокова периода эмиграции - это причудливое переплетение мировых культурных ассоциаций, реминисценций, дискурсов, навеянных памятью поэта. Она показательна и ценна своим активным включением в метаконструкцию художественного мира писателя богатства мирового наследия. Набоков органически вводит в текст своих произведений те факты культуры, которые стали естественной частью европейской и, в целом, мировой цивилизации.

Восток стал важным сегментом этого мирового культурного пространства. Мотивы и образы и восточного мира, поэтическая стилистика персидской литературы предстали в раннем русскоязычном творчестве Набокова важнейшим сегментом культурной памяти человечества, неотъемлемой частью мирового духовного наследия, нашедшими свое достойное место в общем процессе духовности мира, Одновременно молодой поэт обогатил русскую ориенталистику, создав свою уникальную интерпретацию Востока. Ориентальные мотивы, образы, эстетика в текстах Набокова - демонстрация нового этапа творческой эволюции восточных традиций в мировой литературе в соответствии с художественными достижениями XX века. 


\section{Литература}

1- Злочевская А.В. (2018). Мистическая метапроза XX века: генезис $и$ метаморфозы: Герман Гессе - Владимир Набоков - Михаил Булгаков. Москва: Изд-во «Алмавест».

2- Каменский 3.А. (1980). Русская философия начала ХІХ века. -М.: Изд-во «Наука».

3- Карпов Н.А. (2017). Романтические контексты Набокова: записки востоковеда. Санкт-Петербург: Изд-во «Санкт-Петербургского университета», $182 \mathrm{c}$.

4- Люксембург А.М. (1998). «Тень русской ветки на мраморе руки» // Набоков В. В. Стихотворения. Ростов - на - Дону: Изд-во «Феникс», 2001. 471 с. С.5- 11.

5- Набоков В.В. (1990). Собрание сочинений в 4-х $m$. Москва: Изд-во «Правда».

6- Набоков В.В. (2002). Стихотворения. Вступ. ст., сост., подгот. текста и примеч М.Э. Маликовой. Санкт-Петербург: Изд-во «Акад. Проект», 655 с.

7- Набоков В.В. (2001). Стихотворения. Ростов - на - Дону: Изд-во «Феникс», $471 \mathrm{c}$.

8- Накарякова А.А. (2016). Персоносфера Владимира Набокова: типологические ряды: диссертация на соискание ученой степени кандидата филологических наук: 10.01.01 / А.А. Накарякова; Место защиты: Уральский федеральный университет, $202 \mathrm{c}$.

9- Погребная Я.В. (2005). "Плоть поэзии и призрак прозрачной прозы...". Лирика В.В. Набокова. Ставрополь: Изд-во «Ставропольского гос. ун-та», 336 с.

10- Пушкин А.С. (1977). Стихотворения. Поэмы. Сказки. Москва: Изд-во «Художественная литература».

11- Сафиулина P.М. (2008). Символика всеединого в поэзии В.А. Жуковского и А.С. Пушкина (К вопросу о суфийских и буддистских источниках образа «гения чистой красоты»») // Известия Академии наук Республики Таджикистан. Отделение общественных наук. 2009, № 2. С. 166-170.

12- Целкова Л.Н. (2011). Романы Владимира Набокова и русская литературная традиция. Москва: Изд-во «Русское слово», 232 с.

13- Яхьяпур Марзие (Yahyapour, М.), Карими-Мотаххар Джанолах (KarimiMotahhar J.) (2018/1396). Вдохновение ширазских поэтов (Саади и Хафиза) в русской поэзии, Research in Persian Language \& Literature (Pizhūhish-i 'zabān va adabīyyāt-i Fārsī), Пажухешгах улум енсани ва моталеат еджтемаи Джахад данешгахи, № 47, С. 163-184, Тегеран, Иран. (На фарси).

\section{Bibliography}

1- Zlochevskaja A.V. (2018). Misticheskaja metaproza XX veka: genezis $i$ metamorfozy: German Gesse - Vladimir Nabokov - Mihail Bulgakov. Moskva: Izdvo «Almavest».

2- Kamenskij Z.A. (1980). Russkaja filosofija nachala HIH veka. M.: Izd-vo «Nauka». 
3- Karpov N.A. (2017). Romanticheskie konteksty Nabokova: zapiski vostokoveda. Sankt-Peterburg: Izd-vo «Sankt-Peterburgskogo universiteta», $182 \mathrm{~s}$.

4- Ljuksemburg A.M. (1998). «Ten' russkoj vetki na mramore ruki» // Nabokov V. V. Stihotvorenija. Rostov - na - Donu: Izd-vo «Feniks», 2001. 471 s. S.5- 11.

5- Nabokov V.V. (1990). Sobranie sochinenij v 4-h t. Moskva: Izd-vo «Pravda».

6- Nabokov V.V. (2002). Stihotvorenija. Vstup. st., sost., podgot. teksta i primech M.Je. Malikovoj. Sankt-Peterburg: Izd-vo «Akad. Proekt», $655 \mathrm{~s}$.

7- Nabokov V.V. (2001). Stihotvorenija. Rostov - na - Donu: Izd-vo «Feniks», 471 s.

8- Nakarjakova A.A. (2016). Personosfera Vladimira Nabokova: tipologicheskie rjady: dissertacija na soiskanie uchenoj stepeni kandidata filologicheskih nauk: 10.01.01 / A.A. Nakarjakova; Mesto zashhity: Ural'skij federal'nyj universitet, 202 s.

9- Pogrebnaja Ja.V. (2005). "Plot' pojezii i prizrak prozrachnoj prozy...". Lirika V.V. Nabokova. Stavropol': Izd-vo «Stavropol'skogo gos. un-ta», $336 \mathrm{~s}$.

10- Pushkin A.S. (1977). Stihotvorenija. Pojemy. Skazki. Moskva: Izd-vo «Hudozhestvennaja literatura».

11- Safiulina R.M. (2008). Simvolika vseedinogo v pojezii V.A. Zhukovskogo i A.S. Pushkina ( $K$ voprosu o sufijskih $i$ buddistskih istochnikah obraza «genija chistoj krasoty») // Izvestija Akademii nauk Respubliki Tadzhikistan. Otdelenie obshhestvennyh nauk. 2009, № 2. S. 166-170.

12- Celkova L.N. (2011). Romany Vladimira Nabokova i russkaja literaturnaja tradicija. Moskva: Izd-vo «Russkoe slovo», 232 s.

13- Jah'japur Marzie, Karimi-Motahhar Dzhanolah (2018/1396). Vdohnovenie shirazskih pojetov (Saadi i Hafiza) v russkoj pojezii, Research in Persian Language \& Literature (Pizhūhish-i 'zabān va adabīyyāt-i Fārsī), Pazhuheshgah ulum ensani va motaleat edzhtemai Dzhahad daneshgahi, № 47, Pp. 163-184, Tegeran, Iran. (Na farsi).

\section{HOW TO CITE THIS ARTICLE}

Сафиулина Р. М. (2020). Oriental Pages of the Early Poetry of V.V. Nabokov. Issledovatel'skiy Zhurnal Russkogo Yazyka $i$ Literatury, 8(2), 165-185.

DOI: 10.29252 /iarll.16.173

URL: http://journaliarll.ir/index.php/iarll/article/view/132

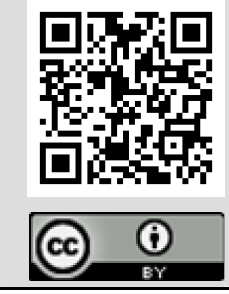




\title{
تصوير شرق در اشعار اوليه و.و. نابوكوف
}

\author{
رعنا ميرزاخانوونا صافيئولينا'

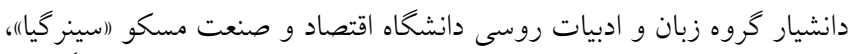 \\ مسكو، روسيه.

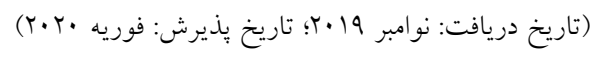

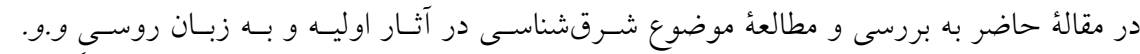

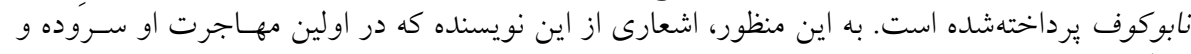

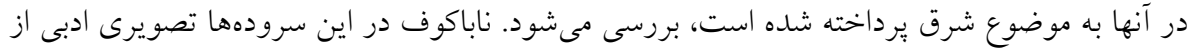

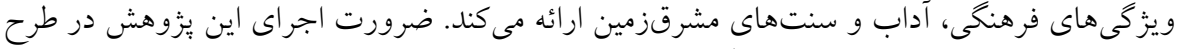

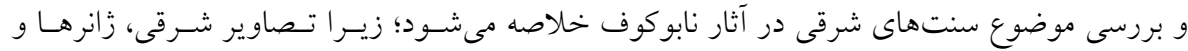

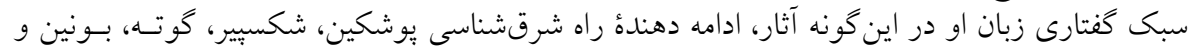

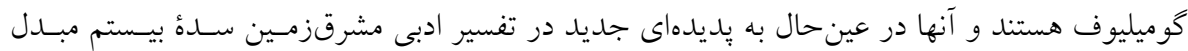

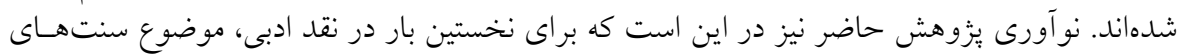

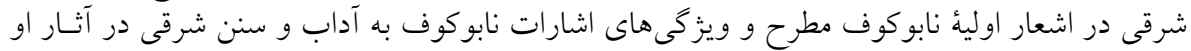

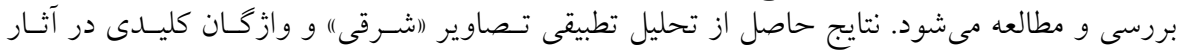

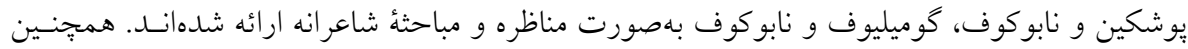

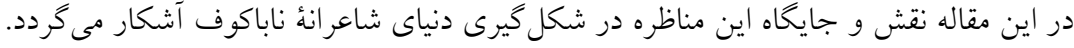

وازگًان كليدى: و.و. نابوكوف، مشرقزمين، شرقشناسى، موضوع اصلى، جند گانكى، ميهن. 